\title{
New Times, New Ways Of Teaching And Learning: Perception Of The EHEA And Pedagogical Discussion
}

José Luis González Geraldo, Ph.D. University of Castilla-La Mancha, Spain Isabel María Ferrándiz Vindel. Ph.D. University of Castilla-La Mancha, Spain Ana María Bordallo Jaén. University of Castilla-La Mancha, Spain

\begin{abstract}
It is 2010, the established deadline of the European Higher Education Area (EHEA). The Bologna Process is an unstoppable reality. But we can not admit that this change, simply by being a significant change, must be for good. We can not also disregard the potential positive pedagogical reform the Bologna Process offers to us. Then, what is the reality of the Bologna Process in Spain? What is the perception of students and teachers? Are there differences in their responses regarding the European Credit Transfer System (ECTS)? What are the pedagogical implications of these answers? This paper provides empirical evidences to these questions through the use of two questionnaires prepared ad hoc according to the pedagogical principles derived from the socalled Bologna Declaration.
\end{abstract}

Keywords: Bologna Process; EHEA; Teaching methodologies; Educative innovation

\section{INTRODUCTION}

2lthough the formal start of the Bologna Process is identified with the Bologna Declaration (1999), their roots are much deeper. The controversial ECTS (also known as ECTAS including the accumulation characteristic) is not an invention of our century. Their origins date back to the late eighties of the twentieth century under the initiative of the Erasmus mobility program. And what is even more, that mobility objective can be found in the very birth of Western universities, nearly a thousand years ago, in what was known as Barbarossa Privilege. A privilege that helped students and scholars who travelled from country to country on behalf of science and did not have a where to stay -amore scientie facti exules- (Thoben, 2002).

Having said that, we can see the Bologna Process principles, at least regarding to mobility, are nothing new and not everything that glitters is gold within the Bologna Process. The EHEA has many aspects that will have positive and negative consequences (Zambrana and Manzano, 2004). In this paper we are going to talk about what we think is one of the main aspects of this change; the pedagogical agenda of the EHEA.

A pedagogical agenda which, at first, perhaps was not as explicit as should have been. In fact, this pedagogical change was not mentioned until the last two biennial conferences of Ministers (London, 2007; Leuven, 2009). This delay has helped to see in the Bologna Process an economic and political change in which harmonization is confused with homogenization and where universities could lose, in a short period of time, what makes higher education, higher.

Regarding this idea, Veiga and Amaral (2009) have stressed the danger of implementing an EHEA in structure, but not in essence. This essence, from our point of view, is the pedagogical change. With this paper, we want to gather evidences about this pedagogical change within the implementation of ECTS regarding both; students and teachers. 
From that rationale, we have elaborated two questionnaires giving special attention to the students' questionnaire, not only because we believe their task are more important than the task of teachers (Shuell, 1986) but also because the psychometric properties of the students' questionnaire were already published (see Bayot et al, 2006) and then results can be compared with those already found.

\section{METHODOLOGY}

In this research we have followed an ex post facto design with semi-control group (see Montero and León, 2005) in which we considered two dichotomous independent variables: 1) Having taught/learned in ECTS and 2) Having received some kind of "ECTS" training (collaborative techniques, time management, student workload schedules, etc.).

The dependent variable was the perception that students and teachers have about pedagogical principles of the EHEA. In order to gather that perception, we have designed two questionnaires with a five scale Likert system in which the respondent could choose between: 1) this item was only rarely or never true for me in this subject and 5) this item was almost always or always true for me in this subject.

The sampling was in two steps. First we asked for volunteers and, at the same time, we did a parametric sampling that could help us to soften the bias of the non parametric one. $\mathrm{N}=2024$ (1924 students and 100 teachers).

Statistically speaking, we did an exploratory factor analysis with principal component extraction. The choice of this method is not trivial or based on the default parameters of the SPSS, which are not always the most appropriate methods (see O'Connor, 2000). This option relies on the needs of the questionnaires; the reduction of data.

Finally, we divided the sample depending on the independent variables mentioned before and carried out an independent $t$ test to search for significant differences between groups regarding the dependent variable.

\section{RESULTS}

Following the Royal Decree 1393/2007 (see BOE, 2007), 66.1\% of the sample belongs to the field of Social Sciences and Law and $65.5 \%$ of the sample are women.

In this research we have used the same questionnaire than in previous researches (see Bayot, Geraldo Gonzalez and Rincon, 2006), known as CPE-EEES (Cuestionario de Percepción del Estudiante en el Espacio Europeo de Educación Superior). After some minor changes we have included a new item ${ }^{1}$ because we find that previous version was not paying attention the possible relationship that students might have with students from other degrees.

The students' questionnaire results corroborate those results already obtained before, but are not identical. In our previous research, already mentioned, we identified five factors: "Methodology", "Information", "Involvement", "Teamwork" and "Coordination" that explained a 57.39\% of the total variance and could be grouped according if the responsibility rested in the teacher (Methodology, Information and Coordination) or in the student (Involvement and teamwork).

After the first factor analysis, we also found five factors accounting for $55.13 \%$ of the total variance but showed some variation regarding the factors mentioned above (Bayot et al, 2006). The changes indicate the link between "Methodology" and "Information" factors, that now were only one factor, and two different loadings of two items: 1) Item 13 ("When I work in group I participate actively") has a load of ,646 in "Teamwork" rather than ,573 that it had in the factor "Involvement" and 2) item 18 ("I have received information on this subject about what the ECTS is and how it works") which forms a new factor with Item 19, first time included in the questionnaire, with a load of ,575.

\footnotetext{
${ }^{1}$ Item 19: "I interact and work with students from other degrees"
} 
With these new results, we identify a new factor (items 18 and 19) calling it "ECTS Information". As we also did in the previous research (Bayot et al, 2006) we have distinguished between those factors in which the teacher's task has a main role (Methodology, Information and Coordination) and those in which the task of the student is the central element (Involvement, Teamwork and the new factor ECTS Information).

To get deeper in these two groups of factors, we carried out two factor analyses more: one regarding to the teacher's factors (Table 1) and the other regarding to the student's factors (Table 2).

Table 1: Rotated Component Matrix: CPE-EEES (teacher's factors)

\begin{tabular}{|c|c|c|c|}
\hline & \multicolumn{3}{|c|}{ Factors } \\
\hline & Methodology & Information/Transparency & Coordination \\
\hline Item 16 & .773 & & \\
\hline Item 14 & .766 & & \\
\hline Item 2 & .704 & & \\
\hline Item 1 & .697 & & \\
\hline Item 11 & & .798 & \\
\hline Item 12 & & .694 & \\
\hline Item 10 & & .587 & \\
\hline Item 4 & & .570 & \\
\hline Item 8 & & & .854 \\
\hline Item 9 & & & .686 \\
\hline
\end{tabular}

Table 2: Rotated Component Matrix: CPE-EEES (student's factors)

\begin{tabular}{|c|c|c|c|}
\hline & \multicolumn{3}{|c|}{ Factors } \\
\hline & Involvement & Teamwork & ECTS Information \\
\hline Item 3 & .790 & & \\
\hline Item 17 & .788 & & \\
\hline Item 6 & .638 & & \\
\hline Item 5 & .620 & & \\
\hline Item 7 & & .808 & \\
\hline Item 15 & & .753 & \\
\hline Item 13 & & .626 & \\
\hline Item 19 & & & .778 \\
\hline Item 18 & & & .696 \\
\hline
\end{tabular}

Comparing the results with the literature (see Bayot et al, 2006), we can see the "Coordination" factor remains as was identified and the other two factors: "Methodology" and "Information" reappear with the exception of item 4 ("I feel that my work is assessed progressively throughout the signature and not only at the end of it") that in this case, has its load in the "Information". Then, from now on, we suggest changing the name of the factor "Information" for the name "Transparency". If we focus on the students" items we can see that the structure does not change.

Regarding results of exploratory factor analysis on the teachers' questionnaire, which from now on we will call it "Cuestionario de Percepción del Entorno Educativo" (CPEE), we would like to comment, first, the KMO test. Although it has an acceptable score (.564) it is quite tight and, therefore, we suggest being careful with these results even when the six factors found explain $70.6 \%$ of the total variance (Table 3 ).

In this case, from a theoretical point of view, we can connect the factors as follows; Sense of TeachingLearning process (Learning and Teaching), External Influences (Control and Peer appreciation) and Teaching Pressure (Ratio and Lack of time). 
Table 3: Rotated Component Matrix: CPEE

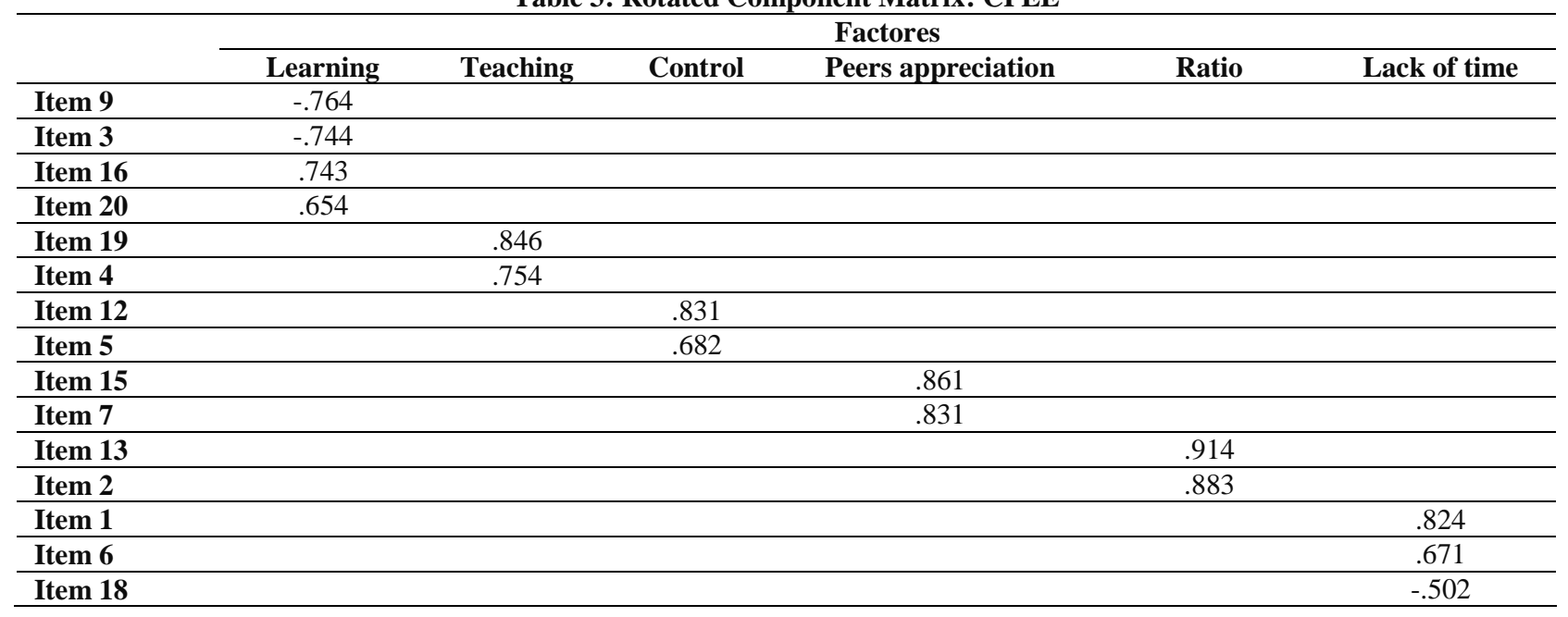

Finally, we compared the means of teachers and students in relation to the factors found in the questionnaires and the variables already mentioned and carried out an independent $t$ test, finding the following significant differences:

Regarding to students (CPE-EEES): A) Having learned in ECTS: significant differences in factors "ECTS Information" ( $\mathrm{t}=10.90 ; \mathrm{p}<0.001)$, "Transparency" $(\mathrm{t}=5.59 ; \mathrm{p}<0.01)$ and "Teamwork" $(\mathrm{t}=-4.22 ; \mathrm{p}<0.001)$. In the first and second cases, they are in favour of the group that worked with ECTS while the latter is in favour of the control group. All represented a small sized effect $(r=.24 ; r=.13 ; r=.12$, respectively). B) Having received some kind of "ECTS" training (their teachers): we find significant differences in the factors "Transparency" $(\mathrm{t}=2.25$; $\mathrm{p}<0.05)$ in favour of the group with "ECTS" teachers, and "Teamwork " $(\mathrm{t}=-3.21 ; \mathrm{p}<0.001)$ in favour of the group. Both of them represented a small sized effect $(r=.10 ; \mathrm{r}=.07)$.

Regarding to teachers (CPEE): A) Having taught in ECTS: significant differences in factors "Learning" ( $\mathrm{t}$ $=-3.10 ; \mathrm{p}<0.01)$, which represented a medium sized effect $(\mathrm{r}=.34)$, "Peer appreciation" $(\mathrm{t}=-2.22 ; \mathrm{p}<0.05)$ and "Lack of time" $(\mathrm{t}=2.74 ; \mathrm{p}<0.01)$, both of them representing a small sized effect $(\mathrm{r}=.22 ; \mathrm{r}=.26$, respectively). The first two are in favour of the ECTS group, while the latter is in favour of the experimental group. B) Having received some kind of "ECTS" training: no significant differences.

\section{DISCUSSION AND PEDAGOGICAL IMPLICATIONS}

On the one hand, the results of students show us the potential of using ECTS; more transparency and more information. However, the perception of group work, one of the keystones of the EHEA is better perceived by students who were not ECTS or did not have ECTS teachers (if we can call them like that). This fact this is a warning that could help us to re-think what kind of group working we are fostering; if it is a real collaborative work or it simply make them work harder and even perhaps is less valued than it should be in the assessment.

On the other hand, the results of teachers show us that the group of teachers who have not worked with ECTS has a better perception of the learning factor and, at the same time, they feel they are better valued by their peers. Finally, teachers who have taught ECTS perceive a higher lack of time, which is quite logical given the demands of such a huge change as the Bologna Process. These data should help us to think about those teachers who could embrace this change without believing in it and are trying to meet the demands of change not for the sake of their students, but just because it is expected to happen. In sum, teachers who could accept the challenge of the EHEA in a lampedusian way, in which everything should change... if we want to keep everything as before. 
In short, the EHEA requires a pedagogical following-up of the process beyond 2010 because we should pursue the real essence of the Bologna Process; learning, and not only the structural change; the degree structure.

\section{AUTHOR INFORMATION}

José Luis González Geraldo: European PhD in Psicopedagogy by University of Castilla-La Mancha (UCLM), Spain. Lecturer in the Department of Education. Particularly interested in the pedagogical change of the EHEA and how it could foster and improve the quality of the teaching-learning process in order to move it towards a learningteaching process. Also interested in approaches to teaching and learning from a student approaches to learning (SAL) perspective. E-mail: joseluis.ggeraldo@uclm.es

Isabel María Ferrándiz Vindel: $\mathrm{PhD}$ in Pedagogy by Complutense University of Madrid (UCM), Spain. Professor in the Department of Education. Interested in inclusive education of disabled people and/or reduced mobility in all educational levels and the training of those professionals who will teach them. E-mail: isabel.ferrandiz@uclm.es

Ana María Bordallo Jaén: UCLM PhD student in Education, Spain. Interested in the school-family relationship. More specifically in the coordination of the parenting program. E-mail: anam.bordallojaen@uclm.es

\section{REFERENCES}

1. Bayot Mestre, A., González Geraldo, J. L. y Del Rincón Igea, B. (2006): “Cuestionario de percepción del EEES por parte del alumnado: propiedades psicométricas iniciales". Revista de la RED-U, 5(1), 49-63.

2. BOE (2007): "REAL DECRETO 1393/2007, de 29 de octubre, por el que se establece la ordenación de las enseñanzas universitarias oficiales". Boletín Oficial del Estado, 260, pp 44037-44048.

3. Bologna Declaration. (1999): The European Higher Education Area. From http://www.ond.vlaanderen.be/hogeronderwijs/bologna/documents/MDC/BOLOGNA_DECLARATION1. pdf. (accessed 09.07.2010).

4. London Communiqué. (2007): Towards the European Higher Education Area: responding to challenges in a globalised world. From http://www.ond.vlaanderen.be/hogeronderwijs/bologna/documents/MDC/London_Communique18May200 7.pdf. (accessed 09.07.2010).

5. Louvain-la-neuve Communiqué. (2009): The Bologna Process 2020: The European Higher Education Area in the new decade. From http://www.ond.vlaanderen.be/hogeronderwijs/bologna/conference/documents/Leuven_Louvain-laNeuve_Communiqué_April_2009.pdf. (accessed 09.07.2010).

6. Montero, I. y León, O. G. (2005): "Sistema de clasificación del método en los informes de investigación en Psicología". International Journal of Clinical and Health Psychology, 5(1), 115-127.

7. O"Connor, B. (2000): "SPSS and SAS programs for determining the number of components using parallel analysis and Velicer"s MAP test". Behavior Research Methods, Instruments \& Computers, 32, 396-402.

8. Shuell, T. J. (1986): “Cognitive conceptions of learning”. Review of Educational Research, 56, 411-436.

9. Thoben, C. (2002): "The European Higher Education Area". German Policy Studies, 2(3), 1-13.

10. Veiga, A. and Amaral, A. (2009). Survey on the implementation of the Bologna process in Portugal. Higher Education, 57-69.

11. Zambrana, L. A. y Manzano Arrondo, V. (2004): “¿Hacia dónde camina la universidad?: Reflexiones acerca del EEES”. Revista Interuniversitaria de Formación del Profesorado, 18(3), 269-276. 
NOTES 